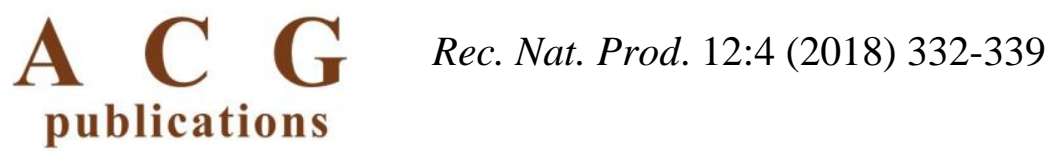

\title{
Antioxidants from Pedicularis longiflora var. tubiformis (Klotzsch) P. C. Tsoong
}

\author{
Yuehui Lan $^{\oplus 1}$, Xiaofeng Chi ${ }^{\oplus 1}$, Guoying Zhou ${ }^{\oplus *}$ and Xiaohui Zhao ${ }^{\oplus 1,2^{*}}$ \\ ${ }^{1}$ Qinghai Key Laboratory of Qinghai-Tibet Plateau Biological Resources, Northwest Institute of \\ Plateau Biology, Chinese Academy of Sciences, Xining 810001, P. R. China \\ ${ }^{2}$ State Key Laboratory of Plateau Ecology and Agriculture, Qinghai University, Xining 810001, P. R. \\ China
}

(Received August 23, 2017; Revised November 17, 2017; Accepted November 18, 2017)

\begin{abstract}
An efficient method for the screening and isolation of potent antioxidants from a tibetan medicinal plant by employing online HPLC-DPPH assay combined HSCCC has been successfully established. Six major constituents: boschnaloside (1), alyssonoside (2), leucosceptoside A (3), isoverbascoside (4), leucosceptoside B (5) and verbascoside (6) were isolated and purified from the water extract by HSCCC using ethyl acetate-nbutanol-water as two-phase solvent system. The results indicated that the combination of the online HPLCDPPH assay with HSCCC could be suitable for the screening and separation of antioxidant compounds from extract of this plant or other medicine plants.
\end{abstract}

Keywords: Pedicularis longiflora var. tubiformis (Klotzsch) P. C. Tsoong; online HPLC-DPPH; HSCCC; antioxidants. (C) 2018 ACG Publications. All rights reserved.

\section{Introduction}

Pedicularis longiflora var. tubiformis (Klotzsch) P. C. Tsoong, belongs to a kind of traditional Tibetan medicinal herbs, and is also recorded in Tibetan medicine, mainly distributed in the northwest and southwest of China [1]. According to the records of Qinghai economic plants, it has a good therapeutic effect on hepatitis, cholecystitis, edema, spermatorrhea and other diseases [2]. The genus Pedicularis is rich in phenolic compounds, and many phenolic compounds have been isolated from other plants of this genus [3]. Although many plants of this genus in the chemical composition have been studied, few papers were about this plant. Previous chemical and pharmacological studies have preliminarily confirmed that phenylpropanoid glycosides, iridoid glycosides and flavonoids are the main chemical constituents and active substances of this plant [4,5]. These kinds of compounds play an important role in human health owing to their antioxidant activities [6-8]. Therefore, the development of convenient and efficient methods to screen and separate antioxidant active substances with higher activity and safety from this plant is highly desirable.

In this paper, a convenient and efficient of online DPPH-HPLC-DAD analysis combined with HSCCC for screening and separation of antioxidants in P. longiflora was successfully developed. Six

\footnotetext{
*Corresponding author: E-Mail: xhzhao@nwipb.cas.cn; Phone:086-971-6143610; Fax:086-971-6143610
} 
major compounds, boschnaloside [9], alyssonoside [10], leucosceptoside A [11,12], isoverbascoside [13], leucosceptoside B [14], and verbascoside [15,16], were screened as antioxidants by on-line DPPH-HPLC-DAD analysis and isolated by HSCCC in one step. The purities of the six compounds were $98.1 \%, 95.7 \%, 96.6 \%, 98.3 \%, 93.2 \%$, and $95.8 \%$, respectively as determined by HPLC. In addition, the DPPH free radical scavenging assay was used to detect the antioxidant activity of the six compounds. All of them showed high radical scavenging activities with the EC50 values being $7.01 \pm 0.54,7.59 \pm 0.29,11.26 \pm 0.32,14.65 \pm 0.83,13.05 \pm 0.31,13.38 \pm 0.46 \mu \mathrm{M}$, respectively. Moreover, boschnaloside, alyssonoside, leucosceptoside A and leucosceptoside B were first separated from this plant.

\section{Materials and Methods}

\subsection{Reagents and Materials}

Analytical grade chemical reagents used for pretreatment and separation were obtained from Tianjin BaiShi chemical industry Co. Ltd (TianJin, China). HPLC grade reagents were purchased from Shandong Yuwang reagent company (Shandong, China). Deionized water was prepared by a Ulupure purification system (Ulupure Corporation, Chengdu, China).

P. longiflora was collected from Hu Zhu, Qinghai province in 2015, and was identified by Professor Qing-bo Gao of Northwest Plateau Institute of Biology, CAS. The complete specimen 200g was stored in the herbarium (Herbarium number: hnwp0330007) of the Northwest Plateau Biological Institute of CAS.

\subsection{Apparatus}

On-line HPLC-DPPH assay was laboratory assembled including an Agilent 1100 series HPLC with a diode array detector (DAD) and an Agilent 1260 series HPLC with a visual web detector (VWD). Polyetheretherketone (PEEK) tubing $(15.0 \mathrm{~m} \times 0.25 \mathrm{~mm}$ i.d.) was used as the reaction coils.

The TBE-300A high speed counter current chromatography equipment (Shanghai Tauto Biotech Co., Ltd., Shanghai, China) was used for HSCCC. A model TBP5002 constant-flow pump (Shanghai Tauto Biotech Co., Ltd., Shanghai, China) was used to pump the solvent system. UV absorbance was detected by a model UV-500 (XUYUKJ Instruments, Hangzhou, China) and recorded by N2000 workstation (Zhejiang University Star Information Technology Co., Ltd., Hangzhou, Zhejiang, China). The system temperature was controlled by an HX-1050 constant temperature circulating implement (Shanghai Shunyuhengping Science Instruments Co. Ltd., Shanghai, China).

A Mercury-600BB NMR spectrometer (Varian Co. Ltd., Palo Alto, CA, USA) with tetramethylsilane (TMS) as the internal standard was used to identify the compounds of I-VI.

\subsection{Preparation of Crude Sample}

The powdered P. longiflora $(1000 \mathrm{~g})$ were extracted by $70 \%$ ethanol for three times $(2 \mathrm{~h}$ each time) under refluxing condition. The extract was concentrated by rotary evaporator under reduced pressure, and $130 \mathrm{~g}$ residue was obtained. The residue was first dissolved by deionized water $(500 \mathrm{~mL})$ and then extracted six times with petroleum ether $(3.0 \mathrm{~L})$. After evaporating the organic solvent, the aqueous fraction was loaded on a macroporous resin column $(100 \mathrm{~cm} \times 6.0 \mathrm{~cm})$, which contains $600 \mathrm{~g}$ D101 macroporous resin, and eluted stepwise with different proportions of water and ethanol (100:0, 80:20, and 60:40, and 40:60 v/v; $3000 \mathrm{~mL}$ for each proportion). The different fractions were concentrated and screened based on the DPPH radical scavenging activity and the $40 \%$ aqueous ethanol (water: ethanol=60:40) fraction exhibited considerable antioxidant effect. Therefore, the $40 \%$ aqueous ethanol fraction ( $30 \mathrm{~g})$ may be a good candidate for further isolation and screening of antioxidant components, which prompted us to perform a detailed target-guided chemical investigation. 


\subsection{Online DPPH Radical-Scavenging Analysis}

Antioxidants in $40 \%$ aqueous ethanol fraction of $P$. longiflora were screened by Online RPHPLC-DPPH method. The instrumental composition, connection and detection process was shown in Figure 1. The fraction (stock concentration $20 \mathrm{mg} / \mathrm{mL}$ ) was analyzed by Agilent 1100 with a Dikma Platisil ODS $\mathrm{C}_{18}$ column $(4.6 \times 250 \mathrm{~mm}$, id $5 \mu \mathrm{m})$. The flow rate was $1.0 \mathrm{~mL} / \mathrm{min}$, detection wavelength was set at $330 \mathrm{~nm}$ and the column temperature was controlled at $25^{\circ} \mathrm{C}$. Methanol - water was used as the mobile phase with a gradient program as follow: 0-45 min, 45-50\% methanol. Online DPPH radical-scavenging assays were performed on Agilent 1260 with the flow rate of DPPH reagent (25 $\mu \mathrm{g} / \mathrm{ml}$ in methanol) at $0.45 \mathrm{~mL} / \mathrm{min}$, and detected at $517 \mathrm{~nm}$ by VWD.
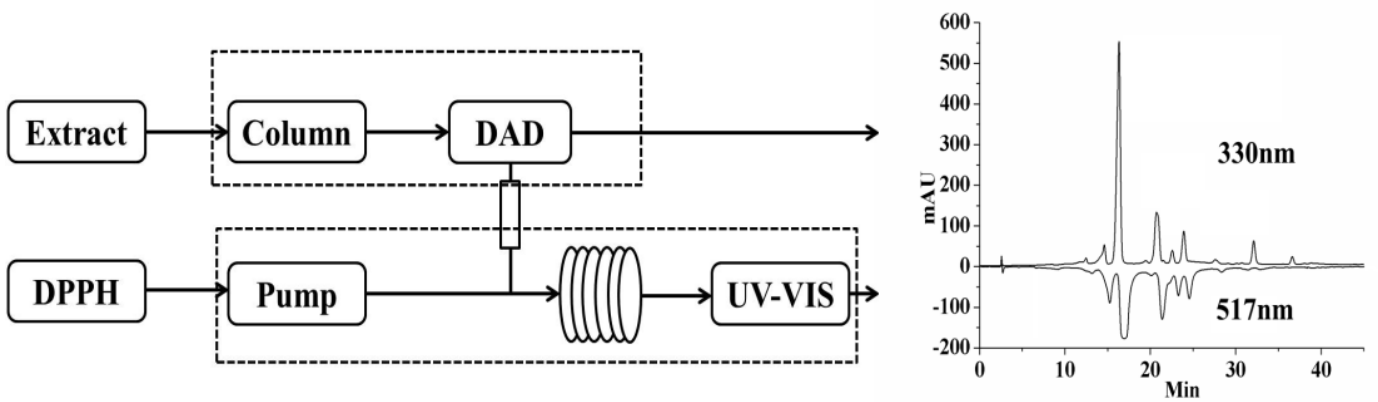

Figure 1. Instrument set-up of on-line system.

\subsection{Measurement of Partition Coefficient of Target Compounds}

The partition coefficient $(\mathrm{K})$ was expressed as the absorbency of sample in the upper phase divided by that in the lower phase. The $\mathrm{K}$ value of crude sample was measured as follow: firstly, 400 mg crude extract was dissolved in a series of pre-equilibrated two-phase-solvent systems. Subsequently, the solution was fully shaken in order to reach the partition equilibrium. At last, the upper and lower phases of equal volumes were evaporated to dryness separately and the residues were diluted into $2 \mathrm{~mL}$ methanol, which were analyzed by HPLC.

\subsection{Preparation of Two-Phase Solvent System and Sample Solution}

Proper solvent system is the key factor for the success of HSCCC separation. The selection of two-phase solvent system plays an important role in the successful separation of high speed countercurrent chromatography. According to the $\mathrm{K}$ value of the targeted compounds, ethyl acetatebutanol-water (13:3:9) was chosen as the solvent system in this experiment. The three solvents are mixed in proportion and placed at room temperature. The upper and lower phases are separated and used before use. The $400 \mathrm{mg}$ sample was dissolved in the lower phase solution of $5 \mathrm{ml}$ as an injection solution.

\subsection{HSCCC Separation Procedure}

First, the coiled column of HSCCC was filled with the upper phase (stationary phase) of solvent system. The lower phase (mobile phase) of solvent system was pumped through the column at a flow rate of $2.5 \mathrm{~mL} / \mathrm{min}$ with the apparatus rotated at $950 \mathrm{rpm} .5 \mathrm{~mL}$ of sample solution containing $400 \mathrm{mg}$ sample was injected through valve when hydrodynamic equilibrium was reached in the column. The peak fractions were collected manually according to the elution profile monitored with a UV detector at $330 \mathrm{~nm}$. The temperature of the apparatus was set to $30^{\circ} \mathrm{C}$. 


\subsection{HPLC analysis and identification of HSCCC peak fractions}

The six peak fractions isolated by HSCCC were analyzed by HPLC based on the analytic conditions mentioned in section 2.4, and the chromatograms are shown in Fig. 4. Meanwhile, peak fraction identification was carried out by ${ }^{1} \mathrm{H}$ and ${ }^{13} \mathrm{C}$ NMR.

\subsection{DPPH radical scavenging activity assays}

The assays of offline DPPH radical scavenging activity were performed according to previously reported protocols [17]. Ascorbic acid (VC) was used as positive control. The DPPH stock solution $(250 \mu \mathrm{M})$ which was firstly prepared with ethanol and stored in the dark at room temperature for $12-16 \mathrm{~h}$ was diluted with ethanol to an absorbance of $0.700( \pm 0.020)$ at $517 \mathrm{~nm}$ before use. $20 \mu \mathrm{L}$ of the compounds were mixed with $180 \mu \mathrm{L}$ of DPPH solution. The mixture was reacted for $30 \mathrm{~min}$ in the dark and then measured at $517 \mathrm{~nm}$ with a UV/vis spectrophotometer (PerkinElmer Enspire, PE, USA) after The radical scavenging activity was determined by the following equation: $\%$ scavenging activity $=[$ Ablank control-Asample $] /$ Ablank control $\times 100 \%$. The EC50 value was obtained through GraphPad Prism 6.02. All determinations were carried out in triplicate.

\section{Results and Discussion}

\subsection{Screening Radical Scavengers Using on-line HPLC-DPPH}

The online HPLC-DPPH method provided a rapid screen of antioxidative components in complex mixtures, particularly plant extracts [18]. Combined UV (positive signals) with DPPH (negative signals) radical quenching chromatograms under gradient conditions of the $40 \%$ aqueous ethanol fraction of $P$. longiflora are presented in Figure 2. Several eluted phytochemicals in the P. longiflora were detected on the UV detector $(330 \mathrm{~nm})$. Among them, six main compounds with high content showed obvious antioxidant capacity (negative peak) toward the DPPH radical at the applied concentration.

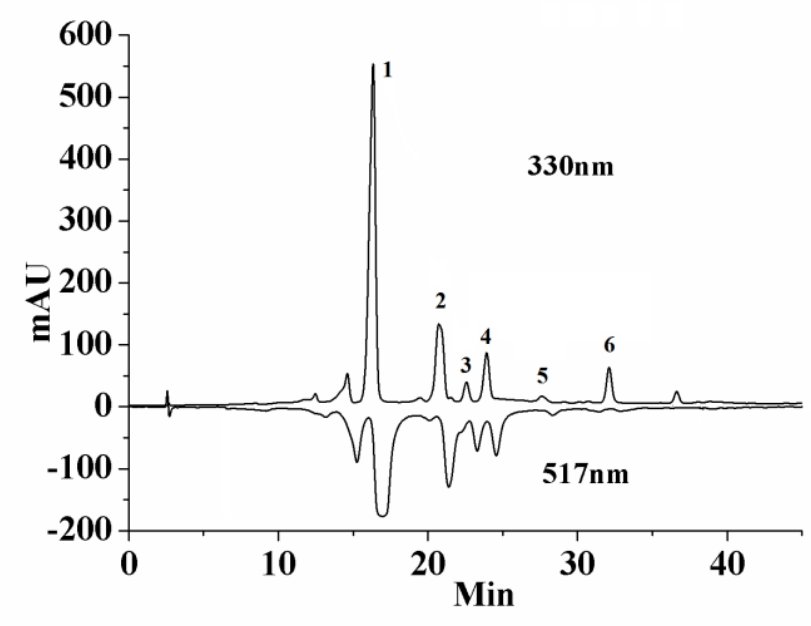

Figure 2. The HPLC chromatograms $(330 \mathrm{~nm})$ and the DPPH radical scavenging chromatograms (517 $\mathrm{nm})$ of the crude extract from P. longiflora.

\subsection{HSCCC Separation}


Six compounds including boschnaloside (1,22 mg), alyssonoside $(2,39 \mathrm{mg})$, leucosceptoside A (3, $27 \mathrm{mg})$, Isoverbascoside $(4,38 \mathrm{mg}), 27 \mathrm{mg}$ of leucosceptoside B $(5,27 \mathrm{mg})$ and verbascoside $(6$, $13 \mathrm{mg}$ ), were generated in one step separation within $8 \mathrm{~h}$ from $400 \mathrm{mg}$ crude sample by using ethyl acetate-n-butanol-water $(13: 3: 9, \mathrm{v} / \mathrm{v} / \mathrm{v})$ as two-phase solvent system at $30^{\circ} \mathrm{C}$ with flow rate of 2.5 $\mathrm{mL} / \mathrm{min}$. The purities of these six compounds were $98.1 \%, 95.7 \%, 96.6 \%, 98.3 \%, 93.2 \%$, and $95.8 \%$, respectively, analyzed by HPLC

\subsection{Structure Elucidation}

The chemical structures of the peak fractions separated by HSCCC as show in Fig. 3 were identified by ${ }^{1} \mathrm{H}$ NMR and ${ }^{13} \mathrm{C}$ NMR data as well as comparison with the published reference data. Results for each peak fraction were as follows.
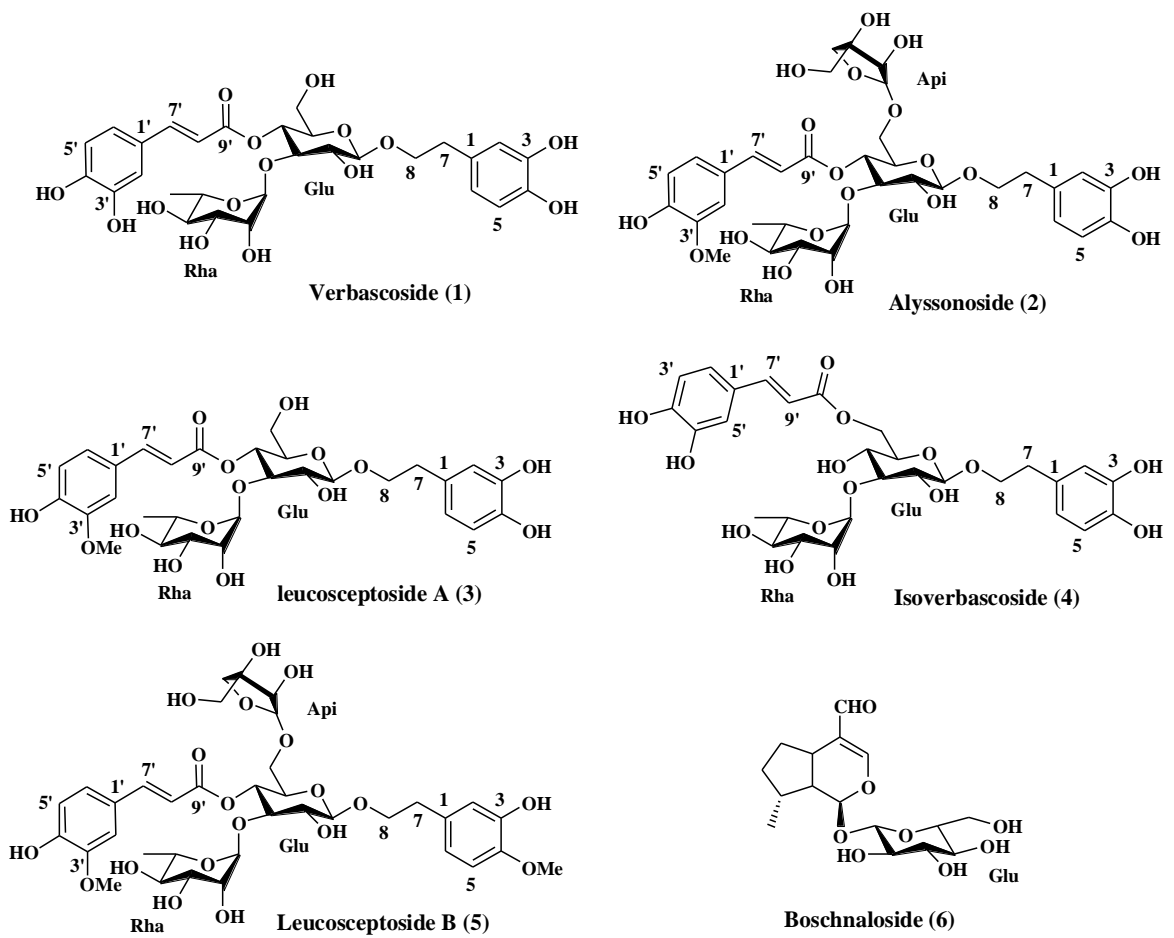

Figure 3. The chemical structures of compounds 1-6

Verbascoside (1): yellow needles, ${ }^{1} \mathrm{H}$ NMR (DMSO- $\left.{ }_{6}, 600 \mathrm{MHz}\right) \delta=7.44(1 \mathrm{H}, \mathrm{d}, \mathrm{J}=15.8 \mathrm{~Hz}$, H-7'), $7.01\left(1 \mathrm{H}, \mathrm{d}, \mathrm{J}=1.9 \mathrm{~Hz}, \mathrm{H}-2^{\prime}\right), 6.96\left(1 \mathrm{H}, \mathrm{dd}, \mathrm{J}=2.0 \mathrm{~Hz}, \mathrm{~J}=8.3 \mathrm{~Hz}, \mathrm{H}-6{ }^{\prime}\right), 6.75(1 \mathrm{H}, \mathrm{d}, \mathrm{J}=7.9$ $\left.\mathrm{Hz}, \mathrm{H}-5^{\prime}\right), 6.62(1 \mathrm{H}, \mathrm{d}, \mathrm{J}=2.2 \mathrm{~Hz}, \mathrm{H}-2), 6.61(1 \mathrm{H}, \mathrm{d}, \mathrm{J}=7.9 \mathrm{~Hz}, \mathrm{H}-5), 6.47(1 \mathrm{H}, \mathrm{dd}, \mathrm{J}=2.0 \mathrm{~Hz}, \mathrm{~J}=$ $8.1 \mathrm{~Hz}, \mathrm{H}-6), 6.19(1 \mathrm{H}, \mathrm{d}, \mathrm{J}=15.9 \mathrm{~Hz}, \mathrm{H}-8$ '), $5.00(1 \mathrm{H}, \mathrm{s}, \mathrm{Rha} \mathrm{H}-1), 4.70(1 \mathrm{H}, \mathrm{t}, \mathrm{J}=9.7 \mathrm{~Hz}$, Glu H-4), $4.34(1 \mathrm{H}, \mathrm{d}, \mathrm{J}=7.9 \mathrm{~Hz}$, Glu H-1), 3.87-3.08 (9H, m, H-8 or Rha/Glu-H), 2.67 (2H, m, H-7), 0.94 (3H, $\mathrm{d}, \mathrm{J}=6.2 \mathrm{~Hz}$, Rha H-6); ${ }^{13} \mathrm{C}$ NMR (DMSO-d $\left.6,150 \mathrm{MHz}\right)=129.1(\mathrm{C}-1), 115.8(\mathrm{C}-2), 143.5(\mathrm{C}-3)$, 145.0 (C-4), 74.5 (Glu C-5), 119.5 (C-6), 35.1 (C-7), 70.2 (C-8), 125.5 (C-1'), 113.6 (C-2'), 148.5 (C3'), 145.5 (C-4'), 116.3 (C-5'), 115.5 (C-5'), 121.4 (C-6'), 145.6 (C-7'), 114.7 (C-8'), 165.7 (C-9'), 102.3 (Glu C-1), 74.4 (Glu C-2), 79.1 (Glu C-3), 68.7 (Glu C-4), 60.7 (Glu C-6), 101.3 (Rha C-1), 70.5 (Rha C-2), 70.3 (Rha C-3), 71.6 (Rha C-4), 69.2 (Rha C-5), 18.3 (Rha C-6) [19].

Alyssonoside (2): yellow needles, ${ }^{1} \mathrm{H}$ NMR (DMSO- $\left.{ }_{6}, 600 \mathrm{MHz}\right) \delta=7.53(1 \mathrm{H}, \mathrm{d}, \mathrm{J}=15.7 \mathrm{~Hz}$, H-7'), $7.28\left(1 \mathrm{H}, \mathrm{d}, \mathrm{J}=1.9 \mathrm{HZ}, \mathrm{H}-2^{\prime}\right), 7.08\left(1 \mathrm{H}, \mathrm{d}, \mathrm{J}=1.9 \mathrm{~Hz}, \mathrm{~J}=8.3 \mathrm{~Hz}, \mathrm{H}-6^{\prime}\right), 6.77(1 \mathrm{H}, \mathrm{d}, \mathrm{J}=8.2 \mathrm{~Hz}$, $\left.\mathrm{H}^{-5}\right), 6.62(1 \mathrm{H}, \mathrm{d}, \mathrm{J}=2.1 \mathrm{~Hz}, \mathrm{H}-2), 6.61(1 \mathrm{H}, \mathrm{d}, \mathrm{J}=8.0 \mathrm{~Hz}, \mathrm{H}-5), 6.49(1 \mathrm{H}, \mathrm{dd}, \mathrm{J}=2.6 \mathrm{~Hz}, \mathrm{~J}=8.0 \mathrm{~Hz}$, H-6), $6.41\left(1 \mathrm{H}, \mathrm{d}, \mathrm{J}=15.9 \mathrm{~Hz}, \mathrm{H}-8^{\prime}\right), 5.01(1 \mathrm{H}, \mathrm{s}, \mathrm{Rha} \mathrm{H}-1), 4.77(1 \mathrm{H}, \mathrm{d}, \mathrm{J}=3.0 \mathrm{~Hz}$, Api H-1), 4.66 $(1 \mathrm{H}, \mathrm{t}, \mathrm{J}=9.7 \mathrm{~Hz}$, Glu H-4), $4.37(1 \mathrm{H}, \mathrm{d}, \mathrm{J}=7.9 \mathrm{~Hz}, \mathrm{Glu} \mathrm{H}-1), 3.79(3 \mathrm{H}, \mathrm{s}, \mathrm{OMe}), 3.77-3.07(15 \mathrm{H}, \mathrm{m}$, H-8 or Rha/Glu/Api-H), 2.68 (2H, m, H-7), $0.96(3 \mathrm{H}, \mathrm{d}, \mathrm{J}=6.2 \mathrm{~Hz}, \mathrm{Rha} \mathrm{H}-6) ;{ }^{13} \mathrm{C}$ NMR (DMSO-d 6 , 
$150 \mathrm{MHz}) \square=129.1$ (C-1), 113.9 (C-2), 145.0 (C-3), 143.5 (C-4), 116.3 (C-5), 119.6 (C-6), 35.0 (C-7), 70.5 (C-8), 125.6 (C-1'), 109.3 (C-2'), 147.9 (C-3'), 149.4 (C-4'), 115.5 (C-5'), 123.3 (C-6'), 145.8 (C-7'), 111.0 (C-8'), 165.9 (C-9'), 55.6 (OMe), 102.2 (Glu C-1), 72.8 (Glu C-2), 78.8 (Glu C-3), 68.8 (Glu C-4), 74.4 (Glu C-5), 67.2 (Glu C-6), 109.1 (Api C-1), 75.9 (Api C-2), 78.7 (Api C-3), 73.4 (Api C-4), 63.1 (Api C-5), 101.3 (Rha C-1), 70.2 (Rha C-2), 70.3 (Rha C-3), 71.6 (Rha C-4), 69.4 (Rha C-5), 18.1 (Rha C-6) [20].

Leucosceptoside A (3): yellow needles, ${ }^{1} \mathrm{H}$ NMR (DMSO- $\left.\mathrm{d}_{6}, 600 \mathrm{MHz}\right) \delta=7.55(1 \mathrm{H}, \mathrm{d}, \mathrm{J}=15.8$ Hz, H-7'), $7.30\left(1 \mathrm{H}, \mathrm{s}, \mathrm{H}-2^{\prime}\right), 7.10\left(1 \mathrm{H}, \mathrm{d}, \mathrm{J}=8.3 \mathrm{~Hz}, \mathrm{H}-6^{\prime}\right), 6.78\left(1 \mathrm{H}, \mathrm{d}, \mathrm{J}=7.9 \mathrm{~Hz}, \mathrm{H}-5^{\prime}\right), 6.62$ (2H, m, $\mathrm{H}-2$ and H-5), $6.43(1 \mathrm{H}, \mathrm{d}, \mathrm{J}=8.1 \mathrm{~Hz}, \mathrm{H}-6), 6.05\left(1 \mathrm{H}, \mathrm{d}, \mathrm{J}=15.9 \mathrm{~Hz}, \mathrm{H}-8^{\prime}\right), 5.03(1 \mathrm{H}, \mathrm{s}, \mathrm{Rha} \mathrm{H}-1)$, $4.72(1 \mathrm{H}, \mathrm{m}, \mathrm{Glu} \mathrm{H}-4), 4.35(1 \mathrm{H}, \mathrm{d}, \mathrm{J}=7.9 \mathrm{~Hz}$, Glu H-1), 3.89-3.10 (9H, m, H-8 or Rha/Glu-H), 3.81 (3H, s, OMe), 2.69 (2H, m, H-7), 0.96 (3H, d, J = 6.2 Hz, Rha H-6); ${ }^{13} \mathrm{C}$ NMR (DMSO-d $6,150 \mathrm{MHz}$ ) $\square=129.1$ (C-1), 115.5 (C-2), 143.5 (C-3), 145.0 (C-4), 116.3 (C-5), 119.5 (C-6), 34.9 (C-7), 70.3 (C8), 125.6 (C-1'), 111.1 (C-2'), 149.4 (C-3'), 147.9 (C-4'), 115.4 (C-5'), 123.1(C-6'), 145.5 (C-7'), 114.1 (C-8'), 165.8 (C-9'), 55.6 (OMe), 102,3 (Glu C-1), 74.5 (Glu C-2), 79.1 (Glu C-3), 68.8 (Glu C-4), 74.6 (Glu C-5), 60.7 (Glu C-6), 101.2 (Rha C-1), 70.5 (Rha C-2), 70.4 (Rha C-3), 71.7 (Rha C-4), 69.1 (Rha C-5), 18.0 (Rha C-6) [19].

Isoverbascoside (4): , yellow needles, ${ }^{1} \mathrm{H}$ NMR (DMSO- $\left.\mathrm{d}_{6}, 600 \mathrm{MHz}\right) \delta=7.45(1 \mathrm{H}, \mathrm{d}, \mathrm{J}=15.7$ $\mathrm{Hz}), 7.04(1 \mathrm{H}, \mathrm{d}, \mathrm{J}=2.0 \mathrm{~Hz}), 6.95(1 \mathrm{H}, \mathrm{dd}, \mathrm{J}=2.0 \mathrm{~Hz}, \mathrm{~J}=8.4 \mathrm{~Hz}), 6.74(1 \mathrm{H}, \mathrm{d}, 8.2 \mathrm{~Hz}), 6.58(1 \mathrm{H}, \mathrm{d}, \mathrm{J}$ $=2 \mathrm{~Hz}), 6.56(1 \mathrm{H}, \mathrm{d}, \mathrm{J}=8.0 \mathrm{~Hz}), 6.44(1 \mathrm{H}, \mathrm{dd}, \mathrm{J}=2.0 \mathrm{~Hz}, \mathrm{~J}=8.0 \mathrm{~Hz}), 6.28(1 \mathrm{H}, \mathrm{d}, \mathrm{J}=15.9 \mathrm{~Hz}), 5.03$ $(1 \mathrm{H}, \mathrm{s}), 4.35(1 \mathrm{H}, \mathrm{d}, \mathrm{J}=10.8 \mathrm{~Hz}$, Glu H-6), $4.26(1 \mathrm{H}, \mathrm{d}, \mathrm{J}=7.6 \mathrm{~Hz}), 4.18(1 \mathrm{H}, \mathrm{m}$, Glu H-6), 3.88-3.10 $(10 \mathrm{H}, \mathrm{m}, \mathrm{Rha} / \mathrm{Glu}-\mathrm{H}), 2.65(2 \mathrm{H}, \mathrm{m}), 1.07(3 \mathrm{H}, \mathrm{d}, \mathrm{J}=6.0 \mathrm{~Hz}) ;{ }^{13} \mathrm{C}$ NMR $\left(\right.$ DMSO-d $\left._{6}, 150 \mathrm{MHz}\right)=129.2$ (C-1), 115.8 (C-2), 143.5 (C-3), 145.0 (C-4), 116.3 (C-5), 119.5 (C-6), 35.1 (C-7), 70.3 (C-8), 125.5 (C-1'), 113.7 (C-2'), 148.4 ((C-3'), 145.3 (C-4'), 115.5 (C-5'), 121.6 (C-6'), 145.6 (C-7'), 114.8 (C-8'), 165.5 (C-9'), 102.7 (Glu C-1), 73.7 (Glu C-2), 80.8 (Glu C-3), 68.6 (Glu C-4), 74.1 (Glu C-5), 63.5 (Glu C-6), 100.7 (Rha C-1), 70.5 (Rha C-2), 70.4 (Rha C-3), 72.1 (Rha C-4), 68.9 ((Rha C-5), 17.9 (Rha C-6) [19].

Leucosceptoside B (5): yellow needles, ${ }^{1} \mathrm{H}$ NMR (DMSO- $\left.\mathrm{d}_{6}, 600 \mathrm{MHz}\right) \delta=7.53(1 \mathrm{H}, \mathrm{d}, \mathrm{J}=15.8$ Hz, H-7'), $7.28\left(1 \mathrm{H}, \mathrm{d}, \mathrm{J}=1.7 \mathrm{HZ}, \mathrm{H}-2^{\prime}\right), 7.07\left(1 \mathrm{H}, \mathrm{d}, \mathrm{J}=1.8 \mathrm{~Hz}, \mathrm{~J}=8.3 \mathrm{~Hz}, \mathrm{H}-6^{\prime}\right), 6.79(1 \mathrm{H}, \mathrm{d}, \mathrm{J}=$ $8.3 \mathrm{~Hz}, \mathrm{H}-5$ '), $6.77(1 \mathrm{H}, \mathrm{d}, \mathrm{J}=8.2 \mathrm{~Hz}, \mathrm{H}-5), 6.67(1 \mathrm{H}, \mathrm{d}, \mathrm{J}=2.2 \mathrm{~Hz}, \mathrm{H}-5), 6.63(1 \mathrm{H}, \mathrm{dd}, \mathrm{J}=2.1 \mathrm{~Hz}, \mathrm{~J}$ $=8.2 \mathrm{~Hz}, \mathrm{H}-6), 6.40\left(1 \mathrm{H}, \mathrm{d}, \mathrm{J}=15.9 \mathrm{~Hz}, \mathrm{H}-8^{\prime}\right), 5.01(1 \mathrm{H}, \mathrm{s}, \mathrm{Rha} \mathrm{H}-1), 4.77(1 \mathrm{H}, \mathrm{d}, \mathrm{J}=2.9 \mathrm{~Hz}$, Api H1), $4.66(1 \mathrm{H}, \mathrm{t}, \mathrm{J}=9.7 \mathrm{~Hz}$, Glu H-4), $4.37(1 \mathrm{H}, \mathrm{d}, \mathrm{J}=7.9 \mathrm{~Hz}$, Glu H-1), 3.87-3.08 (15H, m, H-8 or Rha/Glu/Api-H), 3.80 (3H, s, OMe), 3.71 (3H, s, OMe), $2.73(2 \mathrm{H}, \mathrm{m}, \mathrm{H}-7), 0.96(3 \mathrm{H}, \mathrm{d}, \mathrm{J}=6.2 \mathrm{~Hz}$, Rha H-6); ${ }^{13} \mathrm{C}$ NMR (DMSO-d $\left.6,150 \mathrm{MHz}\right)=131.1(\mathrm{C}-1), 116.3(\mathrm{C}-2), 145.9$ (C-3), 146.1 (C-4), 112.3 (C-5), 119.4 (C-6), 35.0 (C-7), 70.5 (C-8), 125.5 (C-1'), 111.0 (C-2'), 149.6 (C-3'), 148.0 (C-4'), 115.5 (C-5'), 123.3 (C-6'), 146.3 (C-7'), 113.8 (C-8'), 165.9 (C-9'), 55.7 (OMe), 55.6 (OMe), 102.2 (Glu C-1), 72.8 (Glu C-2), 78.8 (Glu C-3), 68.8 (Glu C-4), 74.4 (Glu C-5), 67.2 (Glu C-6), 109.1 (Api C-1), 75.9 (Api C-2), 78.7 (Api C-3), 73.4 (Api C-4), 63.2 (Api C-5), 101.3 (Rha C-1), 70.2 (Rha C-2), 70.4 (Rha C-3), 71.7 (Rha C-4), 69.4 (Rha C-5), 18.2 (Rha C-6) [19].

Boschnaloside (6): yellow needles, ${ }^{1} \mathrm{H}$ NMR (DMSO- $\left.\mathrm{d}_{6}, 600 \mathrm{MHz}\right) \delta=9.17(\mathrm{~s}, 1 \mathrm{H}), 7.37(1 \mathrm{H}, \mathrm{s}$, H-3), $5.63(1 \mathrm{H}, \mathrm{d}, \mathrm{J}=3.0 \mathrm{~Hz}, \mathrm{H}-1), 4.69(1 \mathrm{H}, \mathrm{d}, \mathrm{J}=7.8 \mathrm{~Hz}, \mathrm{H}-1), 3.90(1 \mathrm{H}, \mathrm{d}, \mathrm{J}=11.4 \mathrm{~Hz}, \mathrm{Glu} \mathrm{H}-1)$, 3.65-3.62 (1H, m, Glu H-2), 3.37-2.92 (5H, m, Glu H-3, H-4, H-5, H-6), 2.29-1.28 (7H, m, H-5, H-6, H-7, H-8, H-9), 1.07 (3H, d, J = 6.0 Hz, H-10); ${ }^{13} \mathrm{C}$ NMR (DMSO-d 6 , $\left.150 \mathrm{MHz}\right) \delta=88.0(\mathrm{C}-1), 154.7$ (C-3), 117.0 (C-4), 27.6 (C-5), 21.8 (C-6), 24.1 (C-7), 22.8 (C-8), 34.6 (C-9), 7.13 (C-10), 183.6 (C11), $90.4\left(\mathrm{C}-1^{\prime}\right), 65.2\left(\mathrm{C}-2^{\prime}\right), 69.0\left(\mathrm{C}-3^{\prime}\right), 62.2\left(\mathrm{C}-4^{\prime}\right), 68.5\left(\mathrm{C}-5^{\prime}\right), 53.4\left(\mathrm{C}-6^{\prime}\right)$ [21].

\subsection{DPPH Scavenging Activity}

Target-isolated compounds from P. longiflora extract by HSCCC were evaluated in vitro for their antioxidant with VC as the standard antioxidant. Primary assay showed that six compounds exhibited relatively better radical scavenging effect at the concentration of $10.00 \mu \mathrm{M}$. (Fig. 4) These compounds were further assayed to obtain the EC50 values for antioxidant activities, and a lower EC50 value 
indicates a higher antioxidant activity. The results showed that boschnaloside, alyssonoside, leucosceptoside A, isoverbascoside, leucosceptoside B and verbascoside had potent free radical scavenging capacities with EC50 values of $13.38 \pm 0.46,7.59 \pm 0.29,11.26 \pm 0.32,14.65 \pm 0.83$, $13.05 \pm 0.31,7.01 \pm 0.54 \mu \mathrm{M}$, respectively. The EC50 value for $\mathrm{VC}$ was $12.29 \pm 0.68 \mu \mathrm{M}$. All of the six target compounds had strong antioxidant activity, and the activities of compounds I, II and III were better than the positive control. This study revealed that the method can precisely screening antioxidant compounds and reduce the experimental task in isolating and purifying non-target phytochemicals.

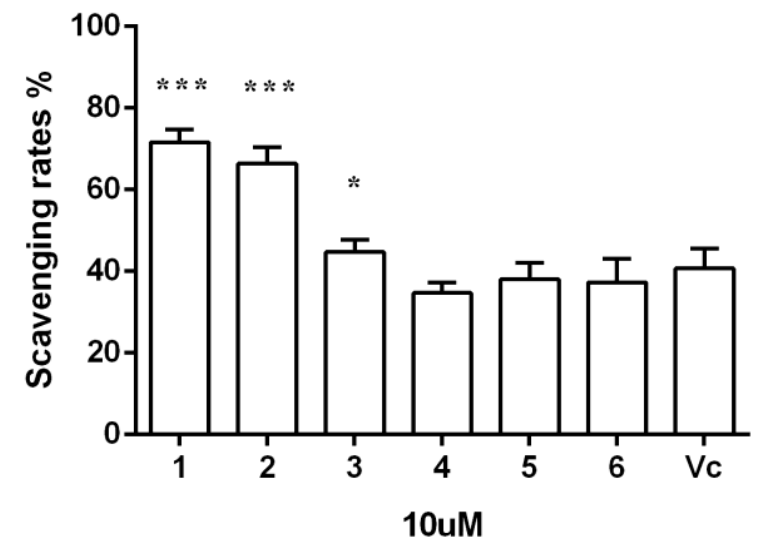

Figure 4. DPPH free radical scavenging rates of six compounds and $\mathrm{VC}$ at a concentration of $10.00 \mu \mathrm{M} ;{ }^{*} \mathrm{p}<0.05$ and $* * * \mathrm{p}<0.001$ versus positive control.

As a conclusion, we have successfully developed an efficient method for the screening and purification of potent antioxidants from the water extract of $P$. longiflora by employing online HPLCDPPH assay combined HSCCC. Six major constituents including boschnaloside, alyssonoside, leucosceptoside A, isoverbascoside, leucosceptoside B and verbascoside with potential antioxidant activity were screened and isolated using this method. Among them, boschnaloside, alyssonoside, leucosceptoside A and leucosceptoside B was obtained from P. longiflora for the first time. The present results indicated that the combination of the online HPLC-DPPH experiment with HSCCC was an efficient method to target-guided isolate antioxidant compounds from natural plants.

\section{Acknowledgments}

This research was supported by the project of QingHai Science and Technology Department Application Fundamental Research (2015-ZJ-726), West Light Foundation of the Chinese Academy of Sciences 2013, The Open Project of State Key Laboratory of Plateau Ecology and Agriculture, Qinghai University (2017-KF-04) and The Project of Qinghai Science \& Technology Department (2016-ZJ-Y01).

\section{ORCID}

Yuehui Lan: $0000-0003-4457-3233$

Xiaofeng chi:0000-0003-0720-8499

Guoying Zhou:0000-0003-2485-6172

Xiaohui Zhao : $\underline{0000-0001-6641-7990}$

\section{References}

[1] Y. C. Yang (1991). Tibetan medicine. Qinghai People's Press, Xining, pp.111-112.

[2] B. Z. Guo (1987). Economic flora of Qinghai. Qinghai People's Press, Xining, pp. 529-530. 
[3] M. I. Yatoo, U. Dimri, A. Gopalakrishnan, K. Karthik, M. Gopi, R. Khandia, M. Saminathan, A. Saxena, M. Alagawany, M. R. Farag, A. Munjal and K. Dhama (2017). Beneficial health applications and medicinal values of Pedicularis plants: A review. Biomed. Pharmacother. 95, 1301-1313.

[4] X. H. Zhao, F. Han, Y. L. Li, G. Y. Zhou and H. L. Yue (2013). Semi-preparative separation and purification of three flavonoids from Pedicularis longiflora var. tubiformis (Klotzsch) P. C. Tsoong by HSCCC, J. Liq. Chromatogr. R. T. 36, 1751-1761.

[5] L. Zhang, H. L. Yue, X. H. Zhao, J. Li and Y. Shao (2015). Separation of four phenylpropanoid glycosides from a Chinese Herb by HSCCC, J. Chromatogr. Sci. 53, 860-865.

[6] M. Georgiev, K. Alipieva, S. Pashova, P. Denev, M. Angelova, G. Kerns and T. Bley (2010). Antioxidant activity of devil's claw cell biomass and its active constituents, Food. Chem. 121, 967-972.

[7] Z. D. He, K. M. Lau, H. X. Xu, P. C. Li and P. P. H. But (2000). Antioxidant activity of phenylethanoid glycosides from Brandisia hancei, J. Ethnopharmacol. 71, 483-486.

[8] B. Sritularak, A (2010). Tantituvanont, P. Chanvorachote, K. Meksawan, T. Miyamoto, Y. Kohno and K. Likhitwitayawuid Flavonoids with free radical scavenging activity and nitric oxide inhibitory effect from the stem bark of Artocarpus gomezianus, J. Med. Plants. Res. 4, 387-392.

[9] L. C. Lin, Y. H. Wang, Y. C. Hou, S. Chang, K. T. Liou, Y. C. Chou, W. Y. Wang and Y. C. Shen (2006). The inhibitory effect of phenylpropanoid glycosides and iridoid glucosides on free radical production and $\beta 2$ integrin expression in human leucocytes, J. Pharm. Pharmacol. 58, 129-135.

[10] A. Boudjelal, C. Henchiri, L. Siracusa, M. Sarin and G. Ruberto (2012). Compositional analysis and in vivo anti-diabetic activity of wild Algerian Marrubium vulgare L. infusion, Fitoterapia 83, 286-292.

[11] D. G. Kanga, Y. S. Lee, H. J. Kim, Y. M. Lee and H. S. Lee (2003). Angiotensin converting enzyme inhibitory phenylpropanoid glycosides from Clerodendron trichotomum, J. Ethnopharmacol. 89, 151154.

[12] Q. Liu, H. J. Hu, P. F. Li, Y. B. Yang, L. H. Wu, G. X. Chou and Z. T. Wang (2014). Diterpenoids and phenylethanoid glycosides from the roots of Clerodendrum bungei and their inhibitory effects against angiotensin converting enzyme and a-glucosidase, Phytochemistry. 103, 196-202.

[13] H. Arthur, E. Joubert, D. D. Beer, C. J. Malherbe, R. C. Witthuhn (2011). Phenylethanoid glycosides as major antioxidants in Lippia multiflora herbal infusion and their stability during steam pasteurisation of plant material, Food Chem. 127, 581-588

[14] M. Georgiev, K. Alipieva, I. Orhan, R. Abrashev, P. Denev and M. Angelova (2011). Antioxidant and cholinesterases inhibitory activities of Verbascum xanthophoeniceum Griseb. and its phenylethanoid glycosides, Food Chem. 128, 100-105.

[15] Y. Wan, B. Zou, H. L. Zeng, L.N. Zhang, M. Chen and G. M Fu (2016). Inhibitory effect of verbascoside on xanthine oxidase activity, Int. J. Biol. Macromol. 93, 609-614.

[16] K. Alipieva, L. Korkina, I. E. Orhan, M. I. Georgiev (2014). Verbascoside--A review of its occurrence, (bio)synthesis and pharmacological significance, Biotechnol. Adv. 32, 1065-1076.

[17] N. Liang, W. Xue, P. Kennepohl and D. D. Kitts (2016).Interactions between major chlorogenic acid isomers and chemical changes in coffee brew that affect antioxidant activities, Food Chem. 213, 251259.

[18] I. I. Koleva, H. A. G. Niederländer and T. A. van BeeK (2000). An on-line HPLC method for detection of radical scavenging compounds in complex mixtures, Anal. Chem. 72, 2323-2328.

[19] T. Miyase, A. Koizumi, A. Ueno, T. Noro, M. Kuroyanagi, S. Fukushima, Y. Akiyama and T. Takemoto (1982). Studies on the acyl glycosides from Leucoseptrum japonicum (Miq.) KITAMURA et MURATA, Chem. Pharm. Bull. 30, 2732-2737.

[20] O. Sticher and O. Salama (1981). Euphroside a new iridoid gheoside from Euphrasia salisburgensis HOPPE, Helv. Chim. Acta. 64, 78-81.

[21] I. Calis, M. Hosny, T. Khalifa and P. Ruedi (1992). Phenylpropanoid glycosides from Marrubium alysson, Phytochemistry 31, 3624-3626.

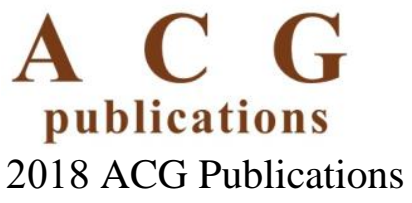

